\title{
Subacute cutaneous lupus erythematosus
}

INSERM

\section{Source}

INSERM. (1999). Orphanet: an online rare disease and orphan drug data base. Subacute cutaneous lupus erythematosus. ORPHA:163525

Subacute cutaneous lupus erythematosus (SCLE) is a form of cutaneous lupus erythematosus (CLE, see this term) that can present either as a non-scarring, annular photo-distributed dermatosis or psoriasiform plaques. SCLE is associated with antiRo/SSA antibodies and can be drug-induced. 